\title{
The Use of Translation Methods in Transfering the Message from the Source Language to the Target Language
}

\author{
Syafryadin $^{1}$, Salniwati ${ }^{2}$, Sitti Kasmiati ${ }^{3}$, Syahrun ${ }^{4}$, Sandy Suseno ${ }^{5}$, Abdul Alim ${ }^{6}$ \\ \{syafryadin@um.ac.id ${ }^{1}$, salniwati@uho.ac.id ${ }^{2}$, sitti.kasmiati@gmail.com ${ }^{3}$, syahrun@gmail.com ${ }^{4}$, \\ sandy.suseno@gmail.com ${ }^{5}$, abdul.alim@gmail.com ${ }^{6}$ \} \\ ${ }^{123456}$ Bengkulu University, Bengkulu, Indonesia
}

\begin{abstract}
There are many ways in transfering the message from the source language to the target language in translation activity. This research investigated dominant translation method and the reasons used by the students at one of department of Halu Oleo University. Descriptive quantitative used as method with random sampling taken of 25 students from 35 students as the population at the students of one of Department in the Cultural Science Faculty of Halu Oleo University in academic year of 2016. The data collection technique was observation with the instrument of observation sheet. Observation sheet as the main data and provided the researchers to the students with contained an abstract in Indonesia Language text with the tittle, "Tradisi Pokadulu pada masyarakat Muna di Desa Walelei Kecamatan Barangka Kabupaten Muna Barat" and the question of the reason of using those methods. The text then was translated by the students into English text using translation methos by Newmark (1988). The students in this research could do that because they had programed English course, Enghlish for oral tradition course, source language course and translation theory course. The technique of data analysis used collecting data, verification, analysis and drawing conclusion. The data were collected, verified, analyzed and drew coclusion derived from the answers on observartion sheet done by the students in this rersearch. The research result showed that dominant method used to deliver the message from source language (Indonesia) to the target language (English) was free translation with total of 16 students. The rest was 7 students used literal translation, semantic for 1 student and 1 student used word for word method. The reason of using dominant method was because free translation gave priority more to the content or the message of source language text than its structure with the aim of message clearer received by the user. It concludes that whatever method used in translation, the most important makes equivalent message from the source language text to the target language text because every language has own cultural aesthetic.
\end{abstract}

Keywords - Translation methods; source language; target language 


\section{Introduction}

Language is a medium of communication that holds a bold function in human life intercation, particularly in delivering the message either between the same language user or different language user. The message addressed from one to another sometimes received misunderstanding. The message in here means information or the meaning delivered by the writter to the reader in writen text. Misunderstanding in interpreting the message from the source language to the target language can affect the original message even eliminates it. This case of course needs proper solution to keep original message or at least equivalent message from the source language to the target language.Wiessbort and Eysteinsson[1] says that the problem of translation is inherent of vital cultural expression both local and global language user. In this point, local and global language user have different tangue. Therefore, translation absolutely needs to comprehend many domain of languges and cultures in the world of literature. Intended meaning of central concepts, expressions and metaphore are also as probem in translation from English to another language such Spanish [2]. Comprehending and interact to the target language input is one of the abvious challenges. Thus, it needs comprehension not only in knowledge and skill of the target language but also to its target culture [3]. This is because target culture affects the meaning emboded in the terget language. Translation process is influenced by personality of the translator in which every personal or individual has different in making decision as well as uses methods of translation in transfering the message from the source language to the target language[4].The problems also found at the students of one of Department in theCultural Science Faculty of Halu Oleo University in academic year of 2016. Based on observation found that the students said English was something hurmfull for them to be understood and practiced, more over they were the students of non-English Department. They are multicultural students with different language, tribe and tradition. So, there are many problems faced the students to comprehend English as the target language (TL) or the source language (SL) in translation. They were the students who program translation theory course in that department. However, some of the studentscould do transposition from Indonesia Language (SL) to the English (TL) but lose original message or information. The other students could understand the message from the English (SL) to Indonesia Language (TL), but miss in doing transposition in form of the text such grammatical errors. This study investigated dominant translation methods used by the students in delivering the message of Indonesia Language text to English text and their reasons of choosing the dominant methods. The methods of translation they used were from Newmark (1988) [5]. These methods are word for word translation, literal translation, faithful translation and semantic translation. These methods emphasis to the source language (SL). The other methos are adaptation, free translation, idiomatic translation and communicative translation. These methods emphasis to the target language (TL). The previous study about translation methods was Umamaheshwari who explained about techniques and methods of translation. He explained completely about the way of translation which included in translation techniques and method such borrowing, calque, literal translation, transposition, modulation, equivalence, adaptation and compensation (www.iosrjournals.org) [6]. Then, Sundari and Husaini searched about translation techniques used by the Indonesia EFL learners such the literal translation, free translation, omission, addition, compensation, word class replacement, explication-implication and paraphrasing [7]. Another researchers investigated about the effect of translation techniques affect toward the quality of translation [8]. It alines with Nur [9] also identified about the technique types of translation in English to Indonesian with the text of abstract of Journal Edunomika 2018. Sundari and Husaini, Nur, as well as Aresta, et all tended to study about translation techniques 
in their researches. They are not the same with the objectives in this paper because the focus of the study were translation methods used by the students of non-English department and their reasons of chosing those methods. In addition, Afifah [10] also studied about translation methods in her reserach, but with translation prosedures prefernce of English Department students Universitas Airlangga on translating Aesop Fables (http://journal.unair.ac.id/download-fullpapers-anglicist3735c051f72full.pdf). Afifah's research was different with this reserach cause the population in this paper were non -English department students and only focused on translation methods while Afifah used English department students and translation procedures. Therefore, disscusion about translation is very importand and in this paper, the researchers aim to study about The Use of Translation Methods in Transfering the Message from the Source Language to the Target Language.

\section{Method}

This study used descriptive quantitative method. Descriptive quantitative method was choosen to analyze the dominant translation methods used by the students and their reasons of selecting them without making any assumption or prediction. All the data collection werestudied clearly and naturally by using numbers to explain natural phenomenon appers in them [11]. The data in this study was observation sheet provided the researchers to the students with contained an abstract in Indonesia Language text with the tittle, "Tradisi Pokadulu pada masyarakat Munadi DesaWalelei Kecamatan Barangka Kabupaten Muna Barat" and the question of the reason of using those methods. That text then was translated by the students into English text used translation methods from Newmark (1988) [5]. The students in this research could do that because they had programed English course, source language course and translation theory course. After the text translated by the students in this research, the data then collected, verified, analized and finally drew conclusion about dominant methods used by the students and the reasons of them of using the dominant methods. The populationof the students in this study were 35 students, but the sample taken were only 25 students under random sampling. Sugiyono [12] says that the bigger samples taken nearly to the population, the smaller generalisation errors happens and vice verse. Therefore, this study only took 25 students as samples cause there were 7 students did not translate the textand 3 students were not active in joining translation theory course. The total of 25 samples were the same to the total of population who did translation of the source language text to the target language text.

\section{Results and Discussions}

The results of this research were derived from the answers on observartion sheet done by the students in this rersearch and then, those data were collected, verified, analyzed and drew coclusion as in the following tables.

The result of the this study shown by the following table: 
Table 1 Preference translation methods of the students, examples and the reasons

\begin{tabular}{|c|c|c|c|}
\hline $\begin{array}{l}\text { Translation } \\
\text { methods }\end{array}$ & $\begin{array}{c}\text { The } \\
\text { students } \\
\text { preference }\end{array}$ & $\begin{array}{l}\text { Perentage } \\
\text { of } \\
\text { preference } \\
(\%)\end{array}$ & The students reason \\
\hline \multicolumn{4}{|c|}{ Emphasis to the source language (SL) } \\
\hline $\begin{array}{l}\text { Word for word } \\
\text { translation }\end{array}$ & 1 & $4 \%$ & $\begin{array}{l}\text { This method was used because it directly positioned } \\
\text { the original source text to the target text version and } \\
\text { called as interlinear translation. The students said that } \\
\text { that method depended on the word orders for } \\
\text { maintaining it and only looked for words equivalence } \\
\text { and general meaning. Example of the student's answer } \\
\text { as follows: } \\
\text { SL: "Hasil penelitian menunjukan bahwa manfaat } \\
\text { tradisi gotong-royong (pokadulu) pada masyarakat di } \\
\text { Desa Walelei Kecamatan Barangka Kabupaten Muna } \\
\text { Barat berupa efisiensi pekerjaan". } \\
\text { TL: "The result of research showed that the benefits of } \\
\text { the mutual coorporation (pokadulu) tradition in the } \\
\text { community in the Walelei Village, Barangka } \\
\text { Subdistrict, West Muna Regency were in the form of } \\
\text { job efficiemcy". } \\
\text { From TL text to SL text above showed that nearly } \\
\text { every single word order Sl was directly translated or } \\
\text { preserved to TL word order such "hasil penelitian" } \\
\text { (SL) to "the result of research" (TL), "menunjukan" } \\
\text { (SL) to "showed" (TL), "manfaat" (SL) to " benefits" } \\
\text { (TL), "tradisi" (SL) to "tradition" (TL) and "gotong- } \\
\text { royong" (SL) to "mutual coorporation" (TL). }\end{array}$ \\
\hline $\begin{array}{l}\text { Faithful } \\
\text { translation }\end{array}$ & 0 & 0 & - \\
\hline $\begin{array}{l}\text { Literal } \\
\text { translation, }\end{array}$ & 7 & $28 \%$ & $\begin{array}{l}\text { The students said that literal translation often called as } \\
\text { structural translation. That method was used because it } \\
\text { could help to solve undefined words as the problem in } \\
\text { the source text to be more natural and equivelent } \\
\text { conversion to the target text.Example of the students } \\
\text { answer as follows: } \\
\text { SL: "Rumusan masalah dalam penelitian ini adalah". } \\
\text { TL: "The formulation of the problem in this research } \\
\text { is". } \\
\text { SL:" sedangkan tujuan penelitian adalah" } \\
\text { TL: "While the research objectives were". } \\
\text { SL:" Metode penelitian menggunakan metode analisis } \\
\text { deskriptif kualitatif". } \\
\text { TL:"The research method used a qualitative } \\
\text { descriptive ananlysis method". } \\
\text { From SL text to TL text above is similar with word for } \\
\text { word trasnlation, however those sentences stucture } \\
\text { were the main focus as the character of literal } \\
\text { translation, such as "adalah " (SL) to "were" (TL), " } \\
\text { menggunakan" (SL) as general structure without any } \\
\text { defenitive time in SL to "used" (TL) as structural or } \\
\text { grammatical form of simple past with defenitive time }\end{array}$ \\
\hline
\end{tabular}




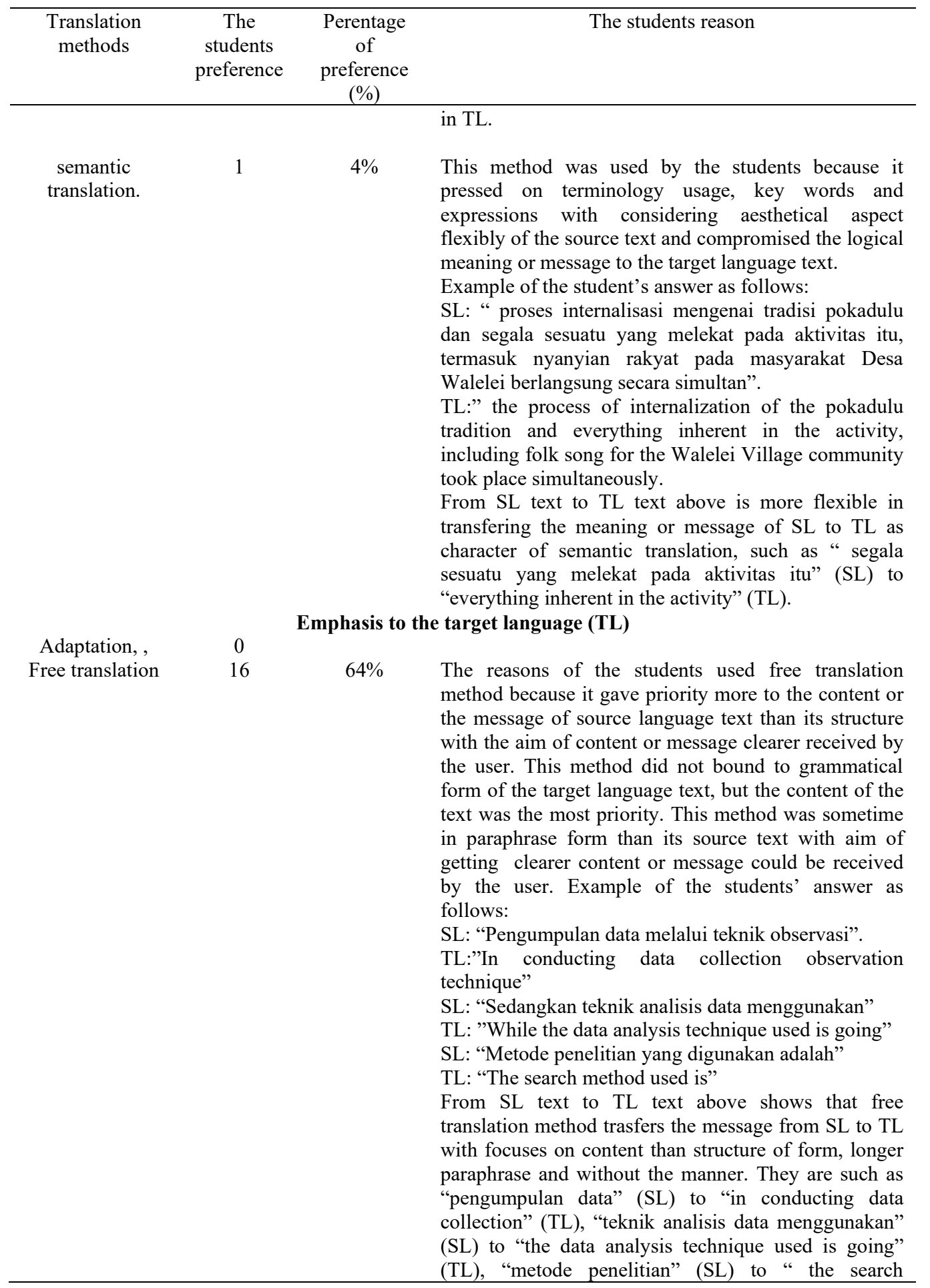




\begin{tabular}{cccc}
\hline $\begin{array}{c}\text { Translation } \\
\text { methods }\end{array}$ & $\begin{array}{c}\text { The } \\
\text { students } \\
\text { preference }\end{array}$ & $\begin{array}{c}\text { Perentage } \\
\text { of } \\
\text { preference } \\
(\%)\end{array}$ & The students reason \\
\hline $\begin{array}{c}\text { Idiomatic } \\
\text { translation }\end{array}$ & 0 & $0 \%$ & method" (TL), "digunakan" (SL) to "used is" (TL). \\
$\begin{array}{c}\text { Communicative } \\
\text { translation }\end{array}$ & 0 & $0 \%$ & - \\
Total number & 25 & $100 \%$ & \\
\hline
\end{tabular}

The table above shows that free translation is the dominant method used by the student with the total of 16 students $(64 \%)$. The other method is literal translation with total of 7 students (28\%), word for word translation for 1 student (4\%), semantic translation for 1 student $(4 \%)$, faithful translation, adaptation, idiomatic and communicative translation is not used by the students. The students have certain reasons of using the methods as shown in the table above. The result of observation sheet done bt the students in this research showen as the following examples. Based on the data above, the reason of using dominant method (free translation) by the students it simply because the students don't have to be limited on the the use of grammatical aspek of source language text in doing the proses of translation to the terget language text. As foreign learner, grammatical aspect is something scary for them to be masted and understood. Therefore, Newmark (1988) with his translation methods provides solution to overcome the students scary in translating particularly to the English,. In addition, The dire need to be understood not only in grammatical aspect, but also in terms of gestures, signs as well as repetition for these, translation comes out as necessary tool to build natural communication and to remove language barriers among society [13]. In aline with this, Tarighi [14] says that the preferred method in translation must be relevant to the original term of the source language text to express the meaning. This view is parallel with the finding of this study that the students used free tanslation method is for nearly closed to the message or meaning of the source language text. Sofyan and Tarigan [15] have other idea on translation that typical characteristics of the target language should be reflected for its fuction and structure to get a good translation product. Sofyan and Tarigan [15] tend to emphasis to the target language to reach good translation. For instance, this study found that in free translation method used by the students, the structure of the source language text is not limitate the structure of the target languge text form, but the meaning or message from the source language text may be received or comprehended into the target language text. Newmark (1988) [5] said that a large numbe of writers preferred free translation because there looked for the spirit not the letter, the sense not the words, the message rather then the form and the matter not the manner. In here, Newmark states that the writers wants the truth in text may be read and understood.It is in accordance with what Burak [16] says that," translation is an activity that can dimage, distort, but in some cases also enhance even improve upon the original text in terms of its cultural-aesthetic impact on the reader".

\section{Conclusion}

There are many translation mathods may be used to transfer the message from the source language text to the target languge text. Free translation is one of translation method choosen by the students with certain reasons as what the reserachers found in this study. However, as the 
student reasons, it is suggested that no matter what translation method is usedfrom the text of source languge to the target language text, the most important makes equivalent message which can be read and understood because every language has own cultural aesthetic.

\section{References}

[1] D.Wiessbort, A. Eysteinsson, Translation-Theory And Practice: A Historical Reader. New York: Oxford University Press, 2006.

[2] A. Hooft, The Way Of The Water: A Reconstruction Of Huastecan Nahua Society Through Its Oral Tradition. Utrecht: Leiden University Press, 2007.

[3] X. Liu, "An audio-visual integrated approach to Japanese and culture," International Journal of Language and Linguistics, vol.6, no. (1), pp. 1-7, 2019.

[4] R. Shaki, (2017), "Personality type and translation performance of Persian translator trainees," Indonesian Journal of Applied Linguistics, vol.7, no. (2), pp. 360-370, 2017.

[5] P. Newmark, A Text Book Of Translation. London: Prentice Hall, 1988.

[6] J. Umamaheshwari, "Techniques and method's of translation," IOSR Journal of Humanities and Social Science (IOSR-JHSS), pp. 40-42. Reatreaved on December 20th 2019 from: (www.iosrjournals.org).

[7] H. Sundari., R. F. Husnaini, "Translation techniques and translation competence in translating informative text for Indonesian EFL learners," Scope: Journal of English Language Teaching, vol. 01, no. (01), pp. 17-28, 2016.

[8] R. Aresta, M.R. Nababan, and Djatmika, "The influence of translation techniques on the accuracy and acceptability of translated utterances that flout the maxim of quality," HUMANIORA, vol. 30, no. (02), pp. 176-191, 2018.

[9] T.F. Nur, "Translation techniques found in English to Indonesian abstract translation of Journal Edunomika 2018," ELITE Journal, vol.05, no. (02), pp. 145-160, 2018.

[10] W. Afifah, "Translation methods and procedures preference of English department students Universitas Airlangga on translating aesop fables," Anglicist, vol. 01, no. (02), pp. 36-42, 2012. Retreaved on December 20th 2019 from: (http://journal.unair.ac.id/download-fullpapersanglicist3735c051f72full.pdf).

[11] W. Walidin, Saifullah, Z.A. and Tabrani, Metodologi Penelitian Kualitatif \& Grounded Theory. Aceh: FTK- Ar Raniry Press, 2015.

[12] Sugiyono, Metode Penelitian Kualitatif, Kuantitatif Dan R \& D. Bandung: Alfabeta, 2009.

[13] N. H. Essa, "The problem German intermediary translation into Arabic (goethe's novel the sorrows of young werther as a model)," International Journal of Language and Lingustics, vol.6, no.(1), pp. 74-80, 2019.

[14] H. Tarighi, "A study of Persian translations of English phrasal verbs in Dan Brown's Inferno," International Journalof Language and Linguistics, vol.5, no. (1), pp. 69-79, 2018.

[15] R. Sofyan, and B. Tarigan, "Theme markedness in the translation of the student translators," Indonesian Journal of Applied inguistics, vol.8, no. (1), pp. 235-243, 2018

[16] [A. Burak, "Unique Rassian-to-English and English-to-Russian translation pedagogy resource," International Journalof Language and Linguistics, vol. 5, no.(4), pp. 14-16, 2018. 